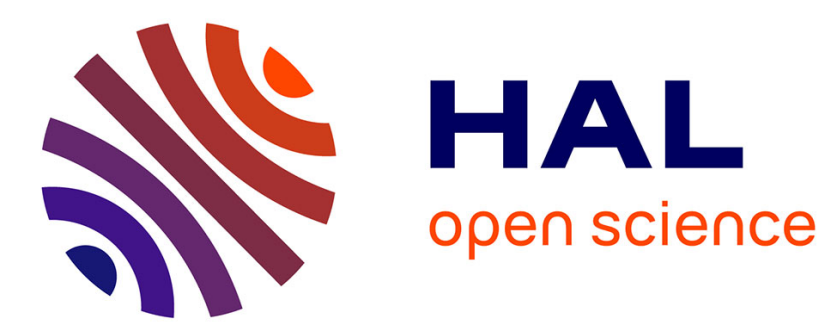

\title{
Synthesis of phosphorylated calix[4]arene derivatives for the design of solid phases immobilizing uranyl cations.
} Agnes Hagege, Zouhair Asfari, Elias Bou-Maroun, Eric Quéméneur, Claude Vidaud

\section{- To cite this version:}

Agnes Hagege, Zouhair Asfari, Elias Bou-Maroun, Eric Quéméneur, Claude Vidaud. Synthesis of phosphorylated calix[4]arene derivatives for the design of solid phases immobilizing uranyl cations.. Supramolecular Chemistry, 2009, 21 (07), pp.585-590. 10.1080/10610270802588301 . hal-00520014

\section{HAL Id: hal-00520014 https://hal.science/hal-00520014}

Submitted on 22 Sep 2010

HAL is a multi-disciplinary open access archive for the deposit and dissemination of scientific research documents, whether they are published or not. The documents may come from teaching and research institutions in France or abroad, or from public or private research centers.
L'archive ouverte pluridisciplinaire HAL, est destinée au dépôt et à la diffusion de documents scientifiques de niveau recherche, publiés ou non, émanant des établissements d'enseignement et de recherche français ou étrangers, des laboratoires publics ou privés. 


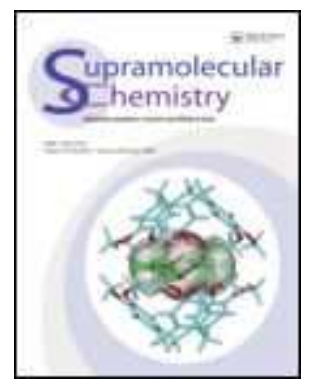

\section{Synthesis of phosphorylated calix[4]arene derivatives for the design of solid phases immobilizing uranyl cations.}

\begin{tabular}{|r|l|}
\hline Journal: & Supramolecular Chemistry \\
\hline Manuscript ID: & GSCH-2008-0138.R1 \\
\hline Manuscript Type: & Full Paper \\
\hline Date Submitted by the & $10-$ Oct-2008 \\
\hline Complete List of Authors: & $\begin{array}{l}\text { HAGEGE, Agnes; CNRS, IPHC-Analytical Sciences } \\
\text { Asfari, Zouhair; CNRS-IPHC } \\
\text { Bou Maroun, Elias; CNRS-IPHC } \\
\text { Quéméneur, Eric; CEA-IBEB-SBTN } \\
\text { Vidaud, Claude; CEA-IBEB-SBTN }\end{array}$ \\
\hline Keywords: & $\begin{array}{l}\text { : Phosphorous-Calix[4]arenes, Uranyl immobilization, Solid } \\
\text { supports, Anchoring arms }\end{array}$ \\
\hline \multicolumn{2}{|c}{} \\
\hline
\end{tabular}

\section{$\diamond$ ScholarONE" \\ Manuscript Central}


With the aim of developing supports for uranyl cation immobilization, new 1,3alternate bearing both phosphonic acid functions as chelating site and $\mathrm{N}$ succinimide-4-oxabutyrate as anchoring arm were synthesized. These compounds were proved to be coupled on a hydrazide gel and to complex uranium successfully.

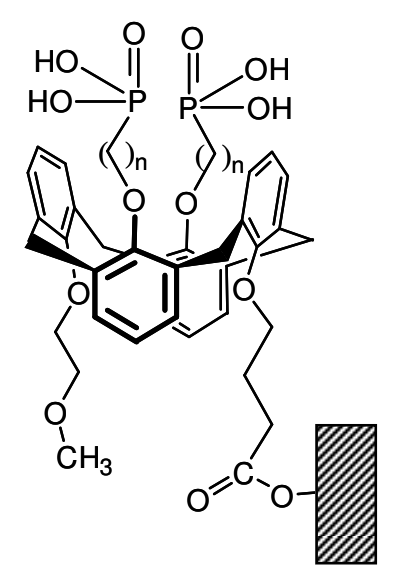

Elias Bou Maroun, Agnès Hagège, Christian Basset, Eric Quéméneur, Claude Vidaud, Zouhair Asfari

Synthesis of new phosphorylated calix[4]arene derivatives for the conception of novel supports immobilizing uranyl. 


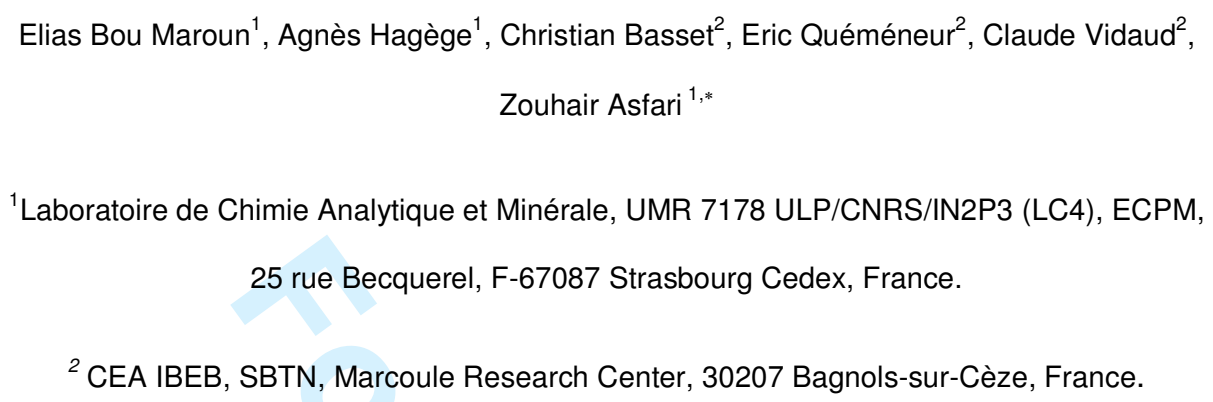

* corresponding author : phone : +33. 3. 90.24.26.94 ; fax : +33. 3. 90.24.27.25 ; e-mail : asfariz@ecpm.u-strasbg.fr 
Keywords: Phosphorous-Calix[4]arenes; Uranyl cations immobilization; Solid supports; Anchoring arms

\section{Introduction}

Uranium, especially under its uranyl ion form $\left(\mathrm{UO}_{2}{ }^{2+}\right)$, js widespread in the environment, naturally occurring in various minerals but also resulting from both nuclear civil and military uses, Regarding to the complexity of biological matrices, studying its speciation in vivo still requires innovative tools. Thus, the design and synthesis of macrocyclic ligands which could preorganize uranyl chelating functions is of primary importance in the development of such tools.

Among them, calixarenes represent an interesting class of macrocycles, On the one hand, they might adopt pseudoplanar configuration. However, in contrast to homooxacalix[4]arenes and Formatted: Indent: First line: 0 pt tetrathiacalix[4]arenes [1-3], the crystal structure of the complex between the simple calix[4]arene and $\mathrm{UO}_{2}{ }^{2+}$ evidenced that the 1,3-oxygen atom distance is far from the ideal distance required for an internal complex [3]. On the other hand, calix[4]arenes can adopt an 1,3-alternate conformation where the uranyl cation binding sites can be remote from the anchoring arm designed for a covalent bond to a polymer support.

Calix[4]arenes functionalized by various complexing groups were then used as extractants of uranyl ion, i.e. carboxylic acid [4-8], carboxylic acid-amide [9,10], ester [11], hydroxamate [12] or semicarbazone functions [13]. Phosphoryl groups have also been proved to be suitable for 
uranyl cation complexation. The solvent extraction of uranium(VI) was widely studied by neutral or acid organo-phosphorus extractants [14-21]. A recent work of Taran et al. reported that bisphosphonates were powerful uranyl ligands [22]. Several papers described the synthesis of phosphonatocalix[4]arenes [23-31]. Some of them were also functionalized with an anchoring arm to be immobilized on solid supports $[7,8,13]$. However, none of these phosphoruscontaining calixarenes were used to extract the uranyl ion.

Consequently, the purpose of the present work was also to provide bifunctional ligands which could simultaneously bind uranium and be immobilized on solid supports.

In this work, the synthesis of two phosphorus-containing calix[4]arenes in the 1,3 alternate conformation bearing both phosphonic acid and $\mathrm{N}$-hydroxysuccinimide ester entities is reported. Their incorporation into a macromolecular matrix is also demonstrated.

\section{Results and discussion}

\section{Conception of uranyl cation immobilizing agents: Synthesis of several (phosphonic} acid)calix[4]arenes

Phosphorus containing calixarenes modified to provide an N-hydroxysuccinimide moiety able to react with $\mathrm{NH}_{2}$ groups of a solid support were synthesized $\mathrm{As}$ it is established that the 1,3alternate conformation of calixarenes seems to be the most favorable for metal complexation [32-34], the synthesis was designed to produce the new calixarenes with this preferred conformation,

Calixarenes 6 and 9 were obtained via a five-step synthesis. The synthetic pathway is illustrated in Fig.4.

[insert figure 1 about here]

Calix[4]arene 1 was first O-alkylated in the presence of $\mathrm{K}_{2} \mathrm{CO}_{3}$ with 1 equivalent of methoxyethoxy-p-toluenesulfonate to obtain the monoalkoxycalix[4]arene 2 in a $68 \%$ yield. The cone conformation stabilized by hydrogen bonds, was revealed by the presence of two $A B$ systems at 4.49 and $3.48 \mathrm{ppm}(J=13.0 \mathrm{~Hz})$ and at 4.31 and $3.46 \mathrm{ppm}(J=13.0 \mathrm{~Hz})$, in the ${ }^{1} \mathrm{H}-$

\begin{tabular}{l} 
Deleted: The aim of this work was to \\
use the potential of $p$ \\
\hline $\begin{array}{l}\text { Deleted: for uranyl complexation and } \\
\text { to modify these ligands so that they }\end{array}$ \\
$\begin{array}{l}\text { Deleted: and far enough away from } \\
\text { the complexation site to allow a } \\
\text { subsequent protein immobilization. }\end{array}$ \\
\hline Formatted: Subscript \\
\hline Deleted: oriented \\
Deleted: obtain \\
Deleted: in such a preferential \\
Deleted:
\end{tabular}


NMR spectrum, attributed to the methylenic protons $\mathrm{ArCH}_{2} \mathrm{Ar}$. The calixarene derivative 2 was then functionalized by reacting 1 equivalent of ethyl-4-bromobutyrate to obtain compound 3 in a $56 \%$ yield. The cone conformation was proved to be maintained by the ${ }^{1} \mathrm{H}$ NMR spectrum of compound 3 which revealed two $A B$ systems at 4.42 and $3.38 \mathrm{ppm}(J=13.0 \mathrm{~Hz})$ and at 4.28 and $3.38 \mathrm{ppm}(J=13.0 \mathrm{~Hz})$, attributed to the methylenic protons $\operatorname{ArCH}_{2} \mathrm{Ar}$.

The introduction of the phosphorus-containing functions was performed by O-alkylation with 2.1 equivalents of diethylphosphonoylmethoxy-p-toluenesulfonate (a) or diethylphosphonoylpropoxy-p-toluenesulfonate (b) in the presence of $\mathrm{K}_{2} \mathrm{CO}_{3}$ to yield calixarene 4 and a mixture of compounds 7 and 7 ' respectively. The 1,3-alternate conformation of compound $\mathbf{4}$ was confirmed by the presence in the ${ }^{1} \mathrm{H}$ NMR spectrum of a singlet for the methylenic protons $\mathrm{ArCH}_{2} \mathrm{Ar}$ at $3.49 \mathrm{ppm}$ and by the ${ }^{31} \mathrm{P}$ NMR spectrum which showed a singlet at $21.8 \mathrm{ppm}$. Compounds $\mathbf{7}$ and $\mathbf{7}$ ' were further separated by gel chromatography and were shown to be the expected diethylphosphonate calix[4]arene in two different conformations. Compound $\mathbf{7}$ was proved to be in the 1,3-alternate conformation, confirmed by the absence of any $A B$ system in the ${ }^{1} \mathrm{H}$ NMR spectrum for the methylenic protons $\mathrm{ArCH}_{2} \mathrm{Ar}$ and the presence of a singlet at $33.5 \mathrm{ppm}$ in the ${ }^{31} \mathrm{P}$ NMR spectrum indicating the presence of two equivalent phosphorous atoms. Compound $\mathbf{7}^{\prime}$ was shown to be in the partial cone conformation. The ${ }^{1} \mathrm{H}$ NMR spectrum revealed an $A B$ system at $4.05 \mathrm{ppm}$ and at $3.09 \mathrm{ppm}(J=13.0 \mathrm{~Hz})$, corresponding to 4 methylenic protons $\mathrm{ArCH}_{2} \mathrm{Ar}$. The singlet corresponding to the other 4 methylenic protons $\mathrm{ArCH}_{2} \mathrm{Ar}$ was located in the multiplet at 3.92-3.57 ppm. The ${ }^{31} \mathrm{P}$ NMR spectrum confirmed this conformation, revealing two singlets at $34.1 \mathrm{ppm}$ and $33.1 \mathrm{ppm}$ for the two different phosphorous atoms.

Calixarenes $\mathbf{5}$ and $\mathbf{8}$ were obtained by transesterification using trimethylbromosilane and subsequent hydrolysis of the trimethylsilylesters in a nearly quantitative yield. Finally, the activation of the carboxylic groups was performed using 2 equivalents of NHS and 2 equivalents of EDC to obtain calixarenes 6 and 9 with a $64 \%$ and a $45 \%$ yield respectively. For all these compounds, the absence of any $A B$ system in the ${ }^{1} \mathrm{H}$ NMR spectra confirmed that the 1,3alternate conformation was maintained. 


\section{Immobilization of calixarenes 6 and 9 on a gel column}

Immobilization was performed by incubating the Ultralink hydrazide gel $\left(15 \mu \mathrm{mol} \mathrm{NH}_{2}\right.$ functions per g) with calixarenes quantities corresponding to $20 \%$ of the total amount of $\mathrm{NH}_{2}$ groups.

Since the calixarenes synthesized in this paper are based on a succinimide ester that is commonly used for reactive amine crosslinking, the ester hydrolysis is a limiting factor. Two buffers were tested for the coupling: a HEPES buffer $(\mathrm{pH} 8.0)$ and a borate buffer $(\mathrm{pH}$ 9.2). A higher $\mathrm{pH}$ was shown to favor the nucleophilic attack to the detriment of the ester hydrolysis, and $\mathrm{pH} 9.2$ was thus used in further experiments.

The repeatability of the coupling was then evaluated on 2 different gels using compound 6 . An average value of $(32 \pm 2) \%(\% \mathrm{~mol})$ of coupled calixarene 6 was found.

The same experiment conducted with calixarene 9 led to $28.5 \%(\% \mathrm{~mol})$, which seems to indicate that the alkyl chain length has no influence on the coupling.

Improvement of the coupling extent was investigated by performing successive calixarene 6 additions and incubations. Results are reported in Table 1 and show that a maximum of $2 \mu \mathrm{mol}$ calixarene 6 / $\mathrm{g}$ gel is obtained.

\section{Immobilization of uranyl ions on a gel column}

Assessment of the complexation efficiency on a modified gel was performed. $1 \mathrm{~g}$ of the Ultralink hydrazide gel coupled with $2 \mu \mathrm{mol}$ calixarene 6 / g was incubated overnight in the presence of 5 equivalents of uranyl acetate. A similar experiment was also conducted with the same quantity of a non-coupled gel. The uranyl cation content in the eluates was quantified and found to be $7.5 \mu \mathrm{mol}$ for the eluates of the gel bound with calixarene 6 and $9.9 \mu \mathrm{mol}$ for the blank. Consequently, $(2.4 \pm 0.1) \mu \mathrm{mol}$ uranyl cation / g were immobilized on the modified gel, which corresponds to a $100 \%$ immobilization (refering to the calixarene). For the non-coupled gel, the immobilized concentration was found to be as low as $(0.1 \pm 0.1) \mu \mathrm{mol}$ uranyl cation / g. It seems then that the immobilization of the uranyl_cation occurs through the formation of a $1: 1$ (uranyl:calixarene) complex. The total release of the uranyl cation from the blank gel shows the Deleted: the presence of calixarene on the gel allows

Deleted: , which is likely to absence of non specific interactions and reinforces this assumption. 


\section{Experimental}

\section{Synthesis}

All reagents and solvents were commercial and were used without further purification. Reagents for the synthesis were all Sigma-Aldrich and Prolabo products Calix[4]arene was prepared according to the literature [35]. Chromatography used $\mathrm{SiO}_{2}$ columns with Kieselgel Merck (art. 11567). The melting points were taken on a Büchi 535 apparatus in capillaries sealed under nitrogen. ${ }^{1} \mathrm{H}$ NMR and ${ }^{31} \mathrm{P}$ NMR spectra were respectively recorded at $300 \mathrm{MHz}$ and $400 \mathrm{MHz}$ on a Bruker Avance spectrometer. For ${ }^{1} \mathrm{H}$ NMR spectra, $\mathrm{CHCl}_{3}(\delta=7.26 \mathrm{ppm})$ was used as an internal standard in $\mathrm{CDCl}_{3}$ and $\mathrm{CHD}_{2} \mathrm{OD}(\delta=3.31 \mathrm{ppm})$ was used as an internal standard in $\mathrm{CD}_{3} \mathrm{OD}$. For ${ }^{31} \mathrm{P}$ NMR spectra, $85 \% \mathrm{H}_{3} \mathrm{PO}_{4}$ was used as an external reference. MALDI-TOF mass spectra were obtained with a Bruker Autoflex II equipped with a $N_{2}$ laser $(\lambda=337 \mathrm{~nm})$ using $\alpha$-cyano-4-hydroxycinnamic acid as matrix. Elemental analyses were performed at the Service de Microanalyse of the Institut de Chimie de Strasbourg. 
1.1 Synthesis of 1,3-[di-(oxamethyl-phosphonic acid)], 2-(N-succinimide-4-oxabutyrate), 4-(methoxyethoxy)-calix[4]-arene (6).

1.11. Mono-methoxyethoxy-calix[4]arene (2). A suspension of calix[4]arene 1 (12.73 $\mathrm{g}, 30.0$ $\mathrm{mmol})$ and $\mathrm{K}_{2} \mathrm{CO}_{3}(2.1 \underline{\mathrm{g}} \mathrm{g}, 15.6 \mathrm{mmol})$ in acetonitrile $(500 \mathrm{~mL})$ was stirred for $30 \mathrm{~min}$ at room temperature under a nitrogen atmosphere. Methoxyethyl $p$-toluenesulfonate $(6,91 \mathrm{~g}, 12.0 \mathrm{mmol})$ was then added and the mixture was stirred and refluxed for 4 days. After removal of the solvent, $400 \mathrm{~mL}$ of $\mathrm{CH}_{2} \mathrm{Cl}_{2}$ and $400 \mathrm{~mL}$ of water were added and the mixture was stirred and acidified with $\mathrm{HCl} 1 \mathrm{M}$. The organic layer was recovered and dried over anhydrous $\mathrm{Na}_{2} \mathrm{SO}_{4}$. After removal of the solvent, compound 2 was purified by column chromatography $\left(\mathrm{SiO}_{2}\right.$, eluent: $\mathrm{CH}_{2} \mathrm{Cl}_{2}$ ) and obtained as a white powder.

Yield: $9.91 \mathrm{~g}(68 \%) \mathrm{mp} 224-225^{\circ} \mathrm{C} .{ }^{1} \mathrm{H}-\mathrm{NMR}(300 \mathrm{MHz}, \mathrm{CDCl} 3) \delta$ (ppm): 9.86 (s, $\left.1 \mathrm{H}, \mathrm{ArOH}\right), 9.24$ (s, 2H, ArOH), 7.12-7.00 (m, 8H, ArH meta $), 6.89\left(\mathrm{t}, 1 \mathrm{H}, J=7.5 \mathrm{~Hz}, \operatorname{ArH}_{\text {para }}\right), 6.72-6.65(\mathrm{~m}, 3 \mathrm{H}$, $\operatorname{ArH}_{\text {para }}$ ), 4.49 (d, 2H, J = 13.0 Hz, ArCH $\mathrm{Ar}_{2}$ ), 4.35-4.32 (m, 2H, $\left.\mathrm{CH}_{2} \mathrm{CH}_{2} \mathrm{OCH}_{3}\right), 4.31$ ( d, 2H, J = 13.0 Hz, ArCH $\mathrm{H}_{2} \mathrm{Ar}$ ), 4.04-4.01 (m, 2H, $\mathrm{CH}_{2} \mathrm{CH}_{2} \mathrm{OCH}_{3}$ ), $3.62(\mathrm{~s}, 3 \mathrm{H}, \mathrm{OCH})_{3}, 3.48(\mathrm{~d}, 2 \mathrm{H}, J=13.0$ $\mathrm{Hz}, \mathrm{ArCH} \mathrm{H}_{2} \mathrm{Ar}$ ), 3.46 (d, 2H, J=13.0 Hz, ArCH $\mathrm{H}_{2} \mathrm{Ar}$ ). Anal. Calcd. for $\mathrm{C}_{31} \mathrm{H}_{30} \mathrm{O}_{5}(\%): \mathrm{C}, 77.16 ; \mathrm{H}$, 6.27. Found C, $77.43 ; \mathrm{H}, 6.00$

1.12. 1-(Ethyl-4-oxabutyrate),_3-(methoxyethoxy)-calix[4]arene (3). Mono-methoxyethoxycalix[4]arene 2 (4 $83 \mathrm{~g}, 10.0 \mathrm{mmol})$ and $\mathrm{K}_{2} \mathrm{CO}_{3}(0.72 \mathrm{~g}, 5.2 \mathrm{mmol})$ were suspended in acetonitrile $(200 \mathrm{~mL})$ and stirred for $1 \mathrm{~h}$ at room temperature under a nitrogen atmosphere. $\mathrm{Br}\left(\mathrm{CH}_{2}\right)_{3} \mathrm{C}(\mathrm{O}) \mathrm{OCH}_{2} \mathrm{CH}_{3}(2.34 \mathrm{~g}, 12.0$ mmol) was then added and the resulting solution was refluxed for 4 days. After evaporation of the solvent in vacuo, the residue was taken up in $\mathrm{CH}_{2} \mathrm{Cl}_{2}(300 \mathrm{~mL})$ and in water $(300 \mathrm{~mL})$ and the resulting mixture was acidified then separated in order to recover the organic layer which was dried over anhydrous $\mathrm{Na}_{2} \mathrm{SO}_{4}$. After evaporation of the solvent, compound $\mathbf{3}$ was purified by column chromatography $\left(\mathrm{SiO}_{2}\right.$, eluent: $\mathrm{CH}_{2} \mathrm{Cl}_{2} /$ acetone $98 / 2 \mathrm{v} / \mathrm{v}$ ) and obtained as a white powder.

Yield: $3.3 \underline{6} \mathrm{~g}(56 \%), \mathrm{mp} 165-166{ }^{\circ} \mathrm{C} .{ }^{1} \mathrm{H}-\mathrm{NMR}\left(300 \mathrm{MHz}, \mathrm{CDCl}_{3}\right) \delta(\mathrm{ppm}): 7.93 \mathrm{~s}(\mathrm{~s}, 2 \mathrm{H}, \mathrm{ArOH})$, $7.06\left(\mathrm{~d}, 4 \mathrm{H}, J=7.5 \mathrm{~Hz}, \operatorname{Ar} H_{\text {meta }}\right), 6.90\left(\mathrm{~d}, 4 \mathrm{H}, J=7.5 \mathrm{~Hz}, \operatorname{Ar} H_{\text {meta }}\right), 6.76-6.71$ (m, $\left.2 \mathrm{H}, \operatorname{Ar} H_{\text {para }}\right)$,

Deleted: 5
Deleted: 56
Deleted: 908

Deleted: 2

\begin{tabular}{|l|}
\hline Deleted: $\mathbf{e}$ \\
\hline Deleted: 826 \\
Deleted: 719 \\
\hline
\end{tabular}

Deleted: 1 


\subsection{Diethylphosphonoylmethoxy-p-toluenesulfonate (a). A solution of triethylamine $(10,12$} g, $100.0 \mathrm{mmol}$ ) in $\mathrm{CH}_{2} \mathrm{Cl}_{2}(50 \mathrm{~mL}$ ) was added dropwise to a stirred mixture of diethyl(hydroxymethyl)phosphonate (8.41 g, $50.0 \mathrm{mmol})$ and p-toluenesulfonyl chloride (10,01 $\mathrm{g}, 52.5 \mathrm{mmol})$ in $\mathrm{CH}_{2} \mathrm{Cl}_{2}(450 \mathrm{~mL})$ at $\mathrm{ca} .0^{\circ} \mathrm{C}$. The resulting mixture was cooled to room temperature and stirred for $15 \mathrm{~h}$. It was then extracted with $300 \mathrm{~mL}$ of acidified aqueous solution and dried over anhydrous $\mathrm{Na}_{2} \mathrm{SO}_{4}$. After removal of the solvent, the residue was purified by column chromatography on silica gel. $\mathrm{CH}_{2} \mathrm{Cl}_{2}$ was used as the first mobile phase then $\mathrm{CH}_{2} \mathrm{Cl}_{2}$ /acetone $(98 / 2, v / v)$. Compound a was recovered as a viscous liquid.

Yield: $\left.12,93 \mathrm{~g}(80 \%) \cdot{ }^{1} \mathrm{H}-\mathrm{NMR}(300 \mathrm{MHz}, \mathrm{CDCl})_{3}\right) \underline{\delta}$ (ppm): 7.79 (d, $\left.2 \mathrm{H}, \mathrm{J}=8.1 \mathrm{~Hz}, \mathrm{ArH}\right), 7.36$ (d, $2 \mathrm{H}, J=8.1 \mathrm{~Hz}, \mathrm{ArH}), 4.19-4.09\left(\mathrm{~m}, 6 \mathrm{H}, \mathrm{SO}_{3} \mathrm{CH}_{2} \mathrm{P}+\mathrm{POOCH}_{2} \mathrm{CH}_{3}\right), 2.45\left(\mathrm{~s}, 3 \mathrm{H}, \mathrm{CH}_{3} \mathrm{Ar}\right), 1.31(\mathrm{t}$, $6 \mathrm{H}, J=7.1 \mathrm{~Hz}, \mathrm{POOCH}_{2} \mathrm{CH}_{3}$ ).

\subsection{1,3-[Dj-(oxamethyl-diethylphosphonate)], 2-(ethyl-4-oxabutyrate), , 4-} (methoxyethoxy)-calix[4]arene (4). A suspension of 1-(ethyl-4-oxabutyrate), 3(methoxyethoxy)-calix[4]arene $3(1.79 \mathrm{~g}, 3.0 \mathrm{mmol})$ and $\mathrm{K}_{2} \mathrm{CO}_{3}(4,15 \mathrm{~g}, 30.0 \mathrm{mmol})$ in acetonitrile $(100 \mathrm{~mL})$ was stirred for $2 \mathrm{~h}$ at room temperature under nitrogen atmosphere. Diethylphosphonoylmethoxy-p-toluenesulfonate a $(2.03 \mathrm{~g}, 6.3 \mathrm{mmol})$ was then added and the mixture was refluxed for 10 days. After filtration of the mixture, the solvent was removed under vacuo and the residue was taken up in $\mathrm{CH}_{2} \mathrm{Cl}_{2}(200 \mathrm{~mL}) .200 \mathrm{~mL}$ of water were added and the mixture was acidified with $1 \mathrm{M} \mathrm{HCl}$. The organic layer was separated, dried over anhydrous $\mathrm{Na}_{2} \mathrm{SO}_{4}$, filtered and concentrated. The resulting residue was purified by column 
chromatography $\left(\mathrm{SiO}_{2}\right.$, eluent: $\mathrm{CH}_{2} \mathrm{Cl}_{2} /$ acetone $\left.90 / 10 \mathrm{v} / \mathrm{v}\right)$. Compound 4 was obtained as a pure yellow viscous liquid.

Yield: $169 \mathrm{~g}(63 \%) .{ }_{-}^{1} \mathrm{H}-\mathrm{NMR}\left(300 \mathrm{MHz}, \mathrm{CDCl}_{3}\right) \delta$ (ppm): 7.25-7.21 (m, 4H, $\left.\mathrm{Ar} \mathrm{H}_{\text {meta }}\right),{ }_{-}$7.11-7.08

Deleted: 687 (m, 2H, ArH $\left.H_{\text {meta }}\right), 6.99-6.96$ (m, 2H, ArH $\left.H_{\text {meta }}\right), 6.68-6.57$ (m, 4H, ArH para $), 4.29-4.17(\mathrm{~m}, 6 \mathrm{H}$, $\left.\mathrm{ArOCH}_{2}+\mathrm{COOCH}_{2} \mathrm{CH}_{3}\right), 4.07\left(\mathrm{~d}, 4 \mathrm{H}, \mathrm{J}=9.2 \mathrm{~Hz}, \mathrm{ArOCH}_{2} \mathrm{P}\right), 3.91-3.88\left(\mathrm{~m}, 2 \mathrm{H}, \mathrm{CH}_{2} \mathrm{OCH}_{3}\right)$, 3.77-3.64 (m, 8H, POOCH $H_{2}$ ), $3.59\left(\mathrm{~s}, 3 \mathrm{H}, \mathrm{CH}_{2} \mathrm{OCH}_{3}\right), 3.49\left(\mathrm{~s}, 8 \mathrm{H}, \mathrm{ArCH}_{2} \mathrm{Ar}\right), 2.53(\mathrm{t}, 2 \mathrm{H}, J=7.2$ $\mathrm{Hz}, \mathrm{CH}_{2} \mathrm{COOEt}$ ), 2.20 (q, 2H, J = $7.2 \mathrm{~Hz}, \mathrm{CH}_{2} \mathrm{CH}_{2} \mathrm{CH}_{2} \mathrm{COOEt}$ ), 1.42 (t, $12 \mathrm{H}, J=7.1 \mathrm{~Hz}$, $\left.\mathrm{POOCH}_{2} \mathrm{CH}_{3}\right), 1.24\left(\mathrm{t}, 3 \mathrm{H}, J=7.1 \mathrm{~Hz}, \mathrm{COOCH}_{2} \mathrm{CH}_{3}\right) .{ }^{31} \mathrm{P} \mathrm{NMR}\left(400 \mathrm{MHz}, \mathrm{CDCl}_{3}\right) \delta(\mathrm{ppm}): 21.8$. Anal. Calcd. for $\mathrm{C}_{47} \mathrm{H}_{62} \mathrm{O}_{13} \mathrm{P}_{2}(\%)$ : C, 62.94; $\mathrm{H}, 6$.97. Found $\mathrm{C}, 62.76 ; \mathrm{H}, 7.14$.

1.15. 1,3-[Dj-(oxamethyl-phosphonic acid)], 2-(4-oxabutyric acid), 4-(methoxyethoxy)calix[4]arene (5). Bromotrimethylsilane $(5,64 \mathrm{~g}, 36.83 \mathrm{mmol}$ ) was added to a solution of compound $4(1.10 \mathrm{~g}, 1.23 \mathrm{mmol})$ in $20 \mathrm{~mL}$ acetonitrile. The reaction mixture was stirred for $24 \mathrm{~h}$

Deleted: $\mathbf{d}$
Deleted: 638
Deleted: 1
at room temperature under nitrogen atmosphere. It was then evaporated under reduced pressure and a mixture of $10 \mathrm{~mL}$ of methanol/water $(50 / 50, \mathrm{v} / \mathrm{v})$ was added to the residue. The resulting solution was stirred at room temperature overnight. After removal of methanol and water, the residue was evaporated twice with $10 \mathrm{~mL}$ of dry toluene and filtered to obtain compound 5 as a pink solid.

Yield: $0.91 \mathrm{~g}(98 \%), \mathrm{mp} 158-159{ }^{\circ} \mathrm{C} .{ }^{1} \mathrm{H}-\mathrm{NMR}\left(300 \mathrm{MHz}, \mathrm{CD}_{3} \mathrm{OD}\right) \delta(\mathrm{ppm}): 7.17$ (d, $4 \mathrm{H}, J=7.5$ Deleted: 2 $\left.\mathrm{Hz}, \operatorname{Ar} H_{\text {meta }}\right)$, 7.05-7.02 (m, 2H, ArH $\left.H_{\text {meta }}\right), 6.95-6.92$ (m, 2H, ArH $\left.H_{\text {meta }}\right), 6.62-6.53$ (m, 4H, ArH $\left.H_{\text {para }}\right)$, 3.76-3.50 (m, $\left.18 \mathrm{H}, \mathrm{ArOCH}_{2} \mathrm{CH}_{2}+\mathrm{ArCH}_{2} \mathrm{Ar}+\mathrm{ArOCH}_{2} \mathrm{P}+\mathrm{CH}_{2} \mathrm{OCH}_{3}\right), 3.22\left(\mathrm{~s}, 3 \mathrm{H}, \mathrm{CH}_{2} \mathrm{OCH}\right)_{3}$, 2.47-2.39 (m, 2H, CH $\delta$ (ppm): 19.9. Anal. Calcd. for $\mathrm{C}_{37} \mathrm{H}_{42} \mathrm{O}_{13} \mathrm{P}_{2}$ (\%): C, 58.73; H, 5.59. Found C, 58.47; H, 5.44. Mass spectrum (MALDI-TOF): $m / z=755.2[\mathrm{M}-\mathrm{H}]$.

1.16. 1,3-[Dij-(oxamethyl-phosphonic acid)], 2-(N-succinimide-4-oxabutyrate), 4(methoxyethoxy)-calix[4]arene (6). Compound 5 (1.14 g, $1.5 \mathrm{mmol})$, EDC [1-Ethyl-3-(3dimethyl-aminopropyl)-carbodiimide $(0.5 \underline{8} \mathrm{~g}, 3.0 \mathrm{mmol})$ and $\mathrm{NHS}(\mathrm{N}-h y d r o x y s u c c i n i m i d e)(0.35$

Deleted: $\mathbf{d}$
Deleted: 35
Deleted: 75
Deleted: 48
$\mathrm{g}, 3.0 \mathrm{mmol}$ ) were dissolved in DMF $(90 \mathrm{~mL})$ and the mixture was stirred overnight at room 
1.2. Synthesis of 1,3-[di-(oxapropyl-phosphonic acid)], 2-(N-succinimide-4-oxabutyrate), 4-(methoxyethoxy)-calix[4]arene (9).

\subsection{Diethylphosphonoylpropoxy-p-toluenesulfonate (b). Diethyl 3-} bromopropylphosphonate $(5.18 \mathrm{~g}, 20.0 \mathrm{mmol})$ and silver p-toluenesulfonate $(11.16 \mathrm{~g}, 40.0$ $\mathrm{mmol}$ ) were dissolved in $200 \mathrm{~mL}$ acetonitrile and stirred at room temperature for 3 days. The solution was then filtered and the solvent was evaporated to dryness under reduced pressure. The residue was then taken up in $\mathrm{CH}_{2} \mathrm{Cl}_{2}(400 \mathrm{~mL})$ and water $(400 \mathrm{~mL})$. The organic layer was recovered and dried over anhydrous $\mathrm{Na}_{2} \mathrm{SO}_{4}$. After removal of the solvent, the residue was purified by column $\left(\mathrm{SiO}_{2}\right.$, eluent: $\mathrm{CH}_{2} \mathrm{Cl}_{2} /$ acetone $\left.80 / 20 \mathrm{v} / \mathrm{v}\right)$. Coumpound $\mathbf{b}$ was recovered as a viscous liquid.

Yield: $1.75 \mathrm{~g}(25 \%) .{ }_{-}^{1} \mathrm{H}-\mathrm{NMR}\left(300 \mathrm{MHz}, \mathrm{CDCl}_{3}\right) \delta(\mathrm{ppm}): 7.78(\mathrm{~d}, 2 \mathrm{H}, \mathrm{J}=8.2 \mathrm{~Hz}, \mathrm{ArH}), 7.34(\mathrm{~d}$, $2 \mathrm{H}, J=8.2 \mathrm{~Hz}, \mathrm{ArH}), 4.12-3.99\left(\mathrm{~m}, 6 \mathrm{H}, \mathrm{CH}_{3} \mathrm{ArSO}_{3} \mathrm{CH}_{2}+\mathrm{POOCH}_{2} \mathrm{CH}_{3}\right.$ ), 2.44 (s, 3H, $\mathrm{CH}_{3} \mathrm{Ar}$ ), 2.01-1.87 (m, $\left.2 \mathrm{H}, \mathrm{SO}_{3} \mathrm{CH}_{2} \mathrm{CH}_{2} \mathrm{CH}_{2} \mathrm{P}\right), 1.81-1.69\left(\mathrm{~m}, 2 \mathrm{H}, \mathrm{SO}_{3} \mathrm{CH}_{2} \mathrm{CH}_{2} \mathrm{CH}_{2} \mathrm{P}\right), 1.29(\mathrm{t}, 6 \mathrm{H}, J=7.1$ $\mathrm{Hz}, \mathrm{POOCH}_{2} \mathrm{CH}_{3}$ ).

\subsection{1,3-[Di-(oxapropyl-diethylphosphonate)], _-(ethyl-4-oxabutyrate), _ 4-} (methoxyethoxy)-calix[4]arene (7 and 7'). The synthesis was performed as for compound 4. Calix[4]arene derivative 3: $1.43 \mathrm{~g}, 2.4 \mathrm{mmol} ; \mathrm{K}_{2} \mathrm{CO}_{3}$ : $3.32 \mathrm{~g}, 24.0 \mathrm{mmol}$; acetonitrile: $100 \mathrm{~mL}$; diethylphosphonoylpropoxy-p-toluenesulfonate b: $1,77 \mathrm{~g}, 5.0 \mathrm{mmol} ; \mathrm{CH}_{2} \mathrm{Cl}_{2}: 200 \mathrm{~mL} ; \mathrm{H}_{2} \mathrm{O}: 200$

Deleted: d

\begin{tabular}{l|} 
Deleted: 2 \\
Deleted: 17 \\
Deleted: 766
\end{tabular}


$\mathrm{mL}$. Column chromatography $\left(\mathrm{SiO}_{2}\right.$, eluent: $\mathrm{CH}_{2} \mathrm{Cl}_{2} /$ acetone $\left.80 / 20 \mathrm{v} / \mathrm{v}\right)$. Compounds 7 and 7 ' were obtained as yellow viscous liquids.

Compound 7 (1,3-alternate), yield: $0,53 \mathrm{~g}(23 \%) .{ }^{1} \mathrm{H}-\mathrm{NMR}\left(300 \mathrm{MHz}, \mathrm{CDCl}_{3}\right) \delta$ (ppm): 7.09-7.06

Deleted: 526 (m, 2H, ArH $\left.H_{\text {meta }}\right), 7.02-7.00\left(\mathrm{~m}, 6 \mathrm{H}, \mathrm{ArH}_{\text {meta }}\right), 6.75-6.70(\mathrm{~m}, 4 \mathrm{H}, \mathrm{ArH}$ para $), 4.21-4.09(\mathrm{~m}, 10 \mathrm{H}$, $\left.\mathrm{ArOCH}_{2}+\mathrm{COOCH}_{2} \mathrm{CH}_{3}\right)$, 3.75-3.55 (m, $\left.16 \mathrm{H}, \mathrm{POOCH}_{2} \mathrm{CH}_{3}+\mathrm{ArCH}_{2} \mathrm{Ar}\right)$, 3.37-3.35 (m, 2H, $\mathrm{CH}_{2} \mathrm{CH}_{2} \mathrm{OCH}_{3}$ ), 3.34 (s, 3H, $\mathrm{CH}_{2} \mathrm{CH}_{2} \mathrm{OCH}_{3}$ ), 2.26 (t, 2H, J = $7.5 \mathrm{~Hz}, \mathrm{CH}_{2} \mathrm{CH}_{2} \mathrm{CH}_{2} \mathrm{COOEt}$ ), 1.92$1.66\left(\mathrm{~m}, 10 \mathrm{H}, \quad \mathrm{CH}_{2} \mathrm{CH}_{2} \mathrm{CH}_{2} \mathrm{POOEt}+\mathrm{CH}_{2} \mathrm{CH}_{2} \mathrm{CH}_{2} \mathrm{COOEt}\right), 1.37(\mathrm{t}, 12 \mathrm{H}, \quad J=7.1 \mathrm{~Hz}$, $\left.\mathrm{POOCH}_{2} \mathrm{CH}_{3}\right), 1.30\left(\mathrm{t}, 3 \mathrm{H}, \mathrm{J}=7.1 \mathrm{~Hz}, \mathrm{COOCH}_{2} \mathrm{CH}_{3}\right) .{ }^{31} \mathrm{P} \mathrm{NMR}\left(400 \mathrm{MHz}, \mathrm{CDCl}_{3}\right) \delta(\mathrm{ppm}): 33.5$ ppm. Anal. Calcd. for $\mathrm{C}_{51} \mathrm{H}_{70} \mathrm{O}_{13} \mathrm{P}_{2}$ (\%): C, 64.27; $\mathrm{H}, 7.40$. Found: $\mathrm{C}, 64.17 ; \mathrm{H}, 7.29$. Mass spectrum (MALDI-TOF): $m / z=975.4\left[\mathrm{MNa}^{+}\right]$.

Compound 7' (partial cone), yield: 0.43 g (19 \%). ${ }^{1} \mathrm{H}-\mathrm{NMR}\left(300 \mathrm{MHz}, \mathrm{CDCl} \mathrm{I}_{3}\right) \delta$ (ppm): 7.35-7.33

Deleted: 4 $\left(\mathrm{m}, 1 \mathrm{H}, \operatorname{Ar} H_{\text {meta }}\right), 7.25-7.22\left(\mathrm{~m}, 1 \mathrm{H}, \operatorname{ArH}_{\text {meta }}\right), 7.10-7.07\left(\mathrm{~m}, 2 \mathrm{H}, \operatorname{Ar} \mathrm{A}_{\text {meta }}\right), 7.01-6.88(\mathrm{~m}, 4 \mathrm{H}$, $\left.\mathrm{ArH}_{\text {meta }}\right), 6.49-6.42\left(\mathrm{~m}, 2 \mathrm{H}, \mathrm{ArH}_{\text {para }}\right), 6.32-6.26\left(\mathrm{~m}, 2 \mathrm{H}, \mathrm{Ar} \mathrm{H}_{\text {para }}\right), 4.21-4.10\left(\mathrm{~m}, 10 \mathrm{H}, \mathrm{ArOCH}_{2}+\right.$ $\left.\mathrm{COOCH}_{2} \mathrm{CH}_{3}\right), 4.05\left(\mathrm{~d}, 2 \mathrm{H}, J=13.0 \mathrm{~Hz}, \mathrm{ArCH} \mathrm{H}_{2} \mathrm{Ar}\right), 3.92-3.57\left(\mathrm{~m}, 12 \mathrm{H}, \mathrm{POOCH}_{2} \mathrm{CH}_{3}+\right.$ $\operatorname{ArCH}_{2} \mathrm{Ar}$ ), 3.45 (s, 3H, $\mathrm{CH}_{2} \mathrm{CH}_{2} \mathrm{OCH}_{3}$ ), 3.09 (d, 2H, J = $\left.13.0 \mathrm{~Hz}, \mathrm{ArCH}_{2} \mathrm{Ar}\right), 2.61-2.43$ (m, 2H, $\mathrm{CH}_{2} \mathrm{CH}_{2} \mathrm{OCH}_{3}$ ), 2.23-2.14 (m, 4H, $\mathrm{CH}_{2}$ POOEt $+\mathrm{CH}_{2} \mathrm{COOEt}$ ), 1.96-1.84 (m, 2H, CH 1.76-1.53 (m, 6H, CH $\left.\mathrm{CH}_{2} \mathrm{CH}_{2} \mathrm{POOEt}+\mathrm{CH}_{2} \mathrm{CH}_{2} \mathrm{CH}_{2} \mathrm{COOEt}\right), 1.43-1.34\left(\mathrm{~m}, 12 \mathrm{H}, \mathrm{POOCH}_{2} \mathrm{CH}_{3}\right)$, $1.26\left(\mathrm{t}, 3 \mathrm{H}, \mathrm{J}=7.1 \mathrm{~Hz}, \mathrm{COOCH}_{2} \mathrm{CH}_{3}\right) .{ }^{31} \mathrm{P} \mathrm{NMR}\left(400 \mathrm{MHz}, \mathrm{CDCl}_{3}\right) \delta(\mathrm{ppm}): 34.1$ and $33.1 \mathrm{ppm}$. Anal. Calcd. for $\mathrm{C}_{51} \mathrm{H}_{70} \mathrm{O}_{13} \mathrm{P}_{2}(\%)$ : C, 64.27; $\mathrm{H}, 7.40$. Found $\mathrm{C}, 64.17 ; \mathrm{H}, 7.29$

1.23. 1,3-[Dj-(oxapropyl-phosphonic acid)], 2-(4-oxabutyric acid), 4-(methoxyethoxy)Deleted: $\mathbf{d}$ calix[4]arene (8). The synthesis was performed as for compound 5.

Calix[4]arene derivative 7: $029 \mathrm{~g}, 0.3 \mathrm{mmol}$; bromotrimethylsilane: $138 \mathrm{~g}, 9.0 \mathrm{mmol}$ acetonitrile: $10 \mathrm{~mL}$; methanol/water $(50 / 50, \mathrm{v} / \mathrm{v}): 5 \mathrm{~mL}$. Pink solid, yield: $024 \mathrm{~g}(98 \%) ; \mathrm{mp} \geq 290$ ${ }^{\circ} \mathrm{C} .{ }^{1} \mathrm{H}-\mathrm{NMR}\left(300 \mathrm{MHz}, \mathrm{CD}_{3} \mathrm{OD}\right) \delta(\mathrm{ppm}): 7.15-7.03\left(\mathrm{~m}, 8 \mathrm{H}, \mathrm{Ar} \mathrm{H}_{\text {meta }}\right), 6.92-6.77$ (m, 4H, $\left.\mathrm{Ar} \mathrm{H}_{\text {para }}\right)$, \begin{tabular}{|l|}
\hline Formatted: Italian Italy \\
\hline Deleted: 286 \\
\hline Deleted: 378 \\
\hline Deleted: 239 \\
\hline
\end{tabular} 3.84-3.49 (m, $\left.18 \mathrm{H}, \mathrm{ArOCH}_{2}+\mathrm{ArCH}_{2} \mathrm{Ar}+\mathrm{CH}_{2} \mathrm{CH}_{2} \mathrm{OCH}_{3}\right), 3.31$ (s, 3H, $\left.\mathrm{CH}_{2} \mathrm{OCH}_{3}\right)$, 2.12-1.98 (m, $\left.2 \mathrm{H}, \mathrm{CH}_{2} \mathrm{COOH}\right), 1.72-1.45\left(\mathrm{~m}, 10 \mathrm{H}, \mathrm{CH}_{2} \mathrm{CH}_{2} \mathrm{CH}_{2} \mathrm{POOH}+\mathrm{CH}_{2} \mathrm{CH}_{2} \mathrm{CH}_{2} \mathrm{COOH}\right.$ ). ${ }^{31} \mathrm{P}$ NMR (400 $\left.\mathrm{MHz}, \mathrm{CD}_{3} \mathrm{OD}\right) \delta(\mathrm{ppm}): 33.5$ ppm. Anal. Calcd. for $\mathrm{C}_{41} \mathrm{H}_{50} \mathrm{O}_{13} \mathrm{P}_{2}(\%)$ : C, 60.59; $\mathrm{H}, 6.20$. Found $\mathrm{C}$, $60.46 ; \mathrm{H}, 6.13$. 
1.24. 1,3-[Dj-(oxapropyl-phosphonic acid)], 2-(N-succinimide-4-oxabutyrate), 4mmol; DMF: $16 \mathrm{~mL}$. Brown solid, yield: $0.11 \mathrm{~g}(45 \%) ; \mathrm{mp}>290{ }^{\circ} \mathrm{C} .{ }^{1}{ }_{-} \mathrm{H}-\mathrm{NMR}(300 \mathrm{MHz}, \mathrm{DMSO}-$ $\left.\mathrm{d}_{6}\right) \delta(\mathrm{ppm}):$ 7.13-6.94 (m, 8H, ArH $\left.\mathrm{H}_{\text {meta }}\right), 6.79-6.69(\mathrm{~m}, 4 \mathrm{H}, \mathrm{ArH}$ para $), 3.66-3.46(\mathrm{~m}, 18 \mathrm{H}, \mathrm{ArOCH}$

\begin{tabular}{l} 
Deleted: 0 \\
Deleted: 4 \\
Deleted: 3 \\
\hline Deleted: 0
\end{tabular}
$\left.+\mathrm{ArCH}_{2} \mathrm{Ar}+\mathrm{ArOCH}_{2} \mathrm{CH}_{2} \mathrm{OCH}_{3}\right), 3.36\left(\mathrm{~s}, 3 \mathrm{H}, \mathrm{CH}_{2} \mathrm{OCH}_{3}\right), 2.71(\mathrm{~s}, 4 \mathrm{H}, \mathrm{NHS}), 1.99-1.88(\mathrm{~m}, 2 \mathrm{H}$, $\mathrm{CH}_{2} \mathrm{COONHS}$ ), $1.57-1.21$ (m, $10 \mathrm{H}, \mathrm{CH}_{2} \mathrm{CH}_{2} \mathrm{CH}_{2} \mathrm{POOH}+\mathrm{CH}_{2} \mathrm{CH}_{2} \mathrm{CH}_{2} \mathrm{COONHS}$ ). ${ }^{31} \mathrm{P}$ NMR (400 $\left.\mathrm{MHz}, \mathrm{DMSO}-\mathrm{d}_{6}\right) \delta$ (ppm): 32.1. Anal. Calcd. for $\mathrm{C}_{45} \mathrm{H}_{53} \mathrm{NO}_{15} \mathrm{P}_{2}(\%): \mathrm{C}, 59.40 ; \mathrm{H}, 5.87 ; \mathrm{N}, 1.54$. Found C, 59.18; H, 5.60; N, 1.60. Mass spectrum not available due to the poor solubility in solvents compatible with mass spectrometry.

\section{Coupling on the solid support}

A column was packed with $1 \mathrm{~g}$ Ultralink hydrazide gel according to the protocol described by the Deleted: $\mathrm{mL}$ manufacturer and conditionned with a $50 \mathrm{mM}$ sodium borate buffer at $\mathrm{pH} 9.40 \mathrm{mg} / \mathrm{mL}$ solutions of compound $\mathbf{6}$ and compound $\mathbf{9}$ were prepared in DMSO. Five successive additions of these solutions were performed in order to obtain a final concentration of $3 \mu \mathrm{mol} / \mathrm{g}$ calixarene and the coupling was performed during $2.5 \mathrm{~h}$ under agitation.

The column was then washed with $2 \times 2 \mathrm{~mL}$ coupling buffer and $2 \mathrm{~mL}$ coupling buffer containing $1 \mathrm{M} \mathrm{NaCl}$ and the eluates were analyzed using a fluorimeter CARY-Eclipse (Varian) at $\lambda_{\text {exc }}=268$ $\mathrm{nm}$ and $\lambda_{\mathrm{em}}=310 \mathrm{~nm}$. $\lambda_{\mathrm{exc}}$ and $\lambda_{\mathrm{em}}$ were previously determined from a calixarene solution and the calixarene amount in the eluates was quantified from a calibration curve $(0 ; 1.86 ; 3.70$; and $\left.7.36 \times 10^{-4} \mathrm{M}\right)$.

The calixarene content was determined from the mass-balance, by difference between the initial number of moles of calixarene and that found in the eluate fractions.

\section{Uranyl cation binding}


Aliquots of gels $(1 \mathrm{~g})$ coupled with $2 \mu$ mol calixarene 6 / g were washed with $4 \times 2$ mL $50 \mathrm{mM}$ sodium acetate buffer $\mathrm{pH} 4.0 .5 \times 20 \mu \mathrm{L}$ of a $0.1 \mathrm{M}$ uranyl acetate solution ( i.e $10 \mu \mathrm{M}$ ) were supernatant was recovered and the column was then rinsed using $3 \times 2 \mathrm{~mL} 50 \mathrm{mM}$ acetate buffer $\mathrm{pH} 4$ and $3 \times 2 \mathrm{~mL} 50 \mathrm{mM}$ HEPES buffer $\mathrm{pH} 7.4$

UV spectra of uranyl solutions, recorded on a CARY 50 (Varian), showed a maximum peak between 222 and $234 \mathrm{~nm}$, correlated to the uranyl concentrations in the solutions. A calibration curve $\left(0 ; 1.5 ; 3\right.$; and $\left.6 \times 10^{-4} \mathrm{M}\right)$ was used to quantify the uranyl amount in both supernatant and eluates. The amount of gel sorbed uranyl cation was determined by difference between its initial quantity and that measured in the liquid fractions.

\section{Acknowledgment}

The authors would like to thank the TOXNUC-E French program for financial support.

\section{References}

[1] Thuéry, P.; Masci, B., Dalton Trans. 2003, 12, 2411-2417.

[2] Masci, B.; Gabrielli, M.; Mortera, S. L.; Nierlich, M.; Thuéry, P. Polyhedron 2002, 21, 11251131.

[3] Asfari, Z. ; Bilyk, A. ; Dunlop, J. W. C.; Hall, A. K. ; Harrowfield, J. M.; Hosseini, M. W.; Skelton, B. W. ; White, A. W. Angew. Chem. Int. Ed. 2001, 40, 721-723.

[4] Montavon, G.; Duplatre, G.; Asfari, Z.; Vicens, J. Solvent Extr. Ion Exch. 1997, 15, 169-188.

[5] Du, Z.; Zhang A.-Y.; Yang Z.-X.; Zhou Z.-M. J. Radioanal. Nucl. Chem. 1999, 241, 241-243.

[6] Montavon, G.; Duplatre, G.; Asfari, Z.; Vicens, J. Radioanal. Nucl. Chem. 1996, 210, 87-103.

[7] Hall, C.W.; Cockayne J.S.; Kan, M.J.; Nicholson G.P. Green Chem. 2001, 3, 114-122.

[8] Evans, C.J.; Nicholson G.P., Sensors and Actuators B 2005, 105, 204-207. 
[9] Beer, P. D.; Brindley, G. D.; Danny Fox, O.; Grieve, A.; Ogden, M. I.; Szemes, F.; Drew, M. G. B. J. Chem. Soc., Dalton Trans. 2002, 16, 3101-3111.

[10] Kan M.J.; Nicholson G.; Horn I., Williams G.; Beer P.D.; Schmitt P.; Hesek D.; Drew M.G.B.; Sheen P. Nucl. Energy 1998, 37, 295-345.

[11] Felinto, M. C. F. C.; Almeida, V. F. J. Alloys and Compounds 2000, 303-304, 524-528.

[12] Agrawal Y.K.; Sanyal M. J. Radioanal. Nucl. Chem. 1995, 198, 349-358.

[13] Jain V.K.; Pandya R.A.; Pillai S.G.; Shrivastav P.S. Talanta 2006, 70, 257-266.

[14] Ghiasvand, A. R.; Mohagheghzadeh, E., Anal. Sci. 2004, 20, 917-919.

[15] Dogmane, S. D.; Singh, R. K.; Bajpai, D. D.; Mathur, J. N., J. Radioanal. Nucl. Chem. 2002, 253, 477-482.

[16] Sarkar, S. G.; Bandekar, S. V.; Dhadke, P. M. J.Radioanal. Nucl. Chem. 2000, 243, 803807.

[17] Singh, D. K.; Singh, H.; Gupta, C. K. J.Radioanal. Nucl. Chem. 2000, 245, 575-580.

[18] Sun, G. X.; Yu, C.; Han, J. T.; Hua, S.; Bao, B. R. J. Radioanal. Nucl. Chem.2000, 246, 431-432.

[19] Someda, H. H.; El Zahhar, A. A.; Shehata, M. K.; El Naggar, H. A. J. of Radioanal. Nucl. Chem.1998, 228, 37-41.

[20] Elias, A.; Rodehuser, L.; Azzouz, A.; Attou, M. Hydrometallurgy 1996, 40, 189-194.

[21] Gatrone, R.C.; Horwitz, E. P.; Rickert P.G., Diamond, H. Solvent Extr. Ion Exch. 1989, 7, 793-811.

[22] Sawicki M., Siaugue J.-M., Jacopin C., Moulin C., Bailly T., Burgada R., Meunier S., Baret P., Pierre J.-L., Taran F., Chem. Eur., 2005, 11, 3689.

[23] Jurecka, P.; Vojtisek, P.; Novotny, K.; Rohovec, J.; Lukes, I. J. Chem. Soc., Perkin Trans. 2 2002, 7, 1370-1377.

[24] Bochenska, M.; Hoffmann, M.; Lesinska, U. J. Incl. Phenom. 2004, 49, 57-60.

[25] Matulkova, I.; Rohovec, J. Polyhedron 2005, 24(2), 311-317.

[26] Ozegowski, S.; Coostisella, B.; Gloede, J. Phosphorus, Sulfur and Silicon and Their Related Elements 1996, 119, 209-223. 
[27] Gloede, J.; Ozegowski, S.; Kockritz, A.; Keitel, I. Phosphorus, Sulfur and Silicon and Their Related Elements 1997, 131, 141-145.

[28] Cherenok, S.; Vovk, A.; Muravyova, I.; Shivanyuk, A.; Kukhar, V.; Lipkowski, J.; Kalchenko, V. Organic Letters 2006, 8, 549-552.

[29] Kyoda, M.; Maekawa, H.; Sadai, Y.; Nishiguchi, I. Adv. Technol. Mat. Mat. Process. J. 2004, 6, 29-36.

[30] Wiit, D.; Dziemidowicz, J.; Rachon, J. Heteroat. Chem. 2004, 15, 155-161.

[31] Hoffmann, M.; Konitz, A.; Lesinska, U.; Bochenska, M.; J. Incl. Phenom. 2003, 47, 137-142.

[32] Casnati, A.; Pochini, A.; Ungaro, R.; Bocchi, C.; Ugozzoli, F.; Egberink, R. J. M.; Struijk, H.; Lugtenberg, R.; de Jong, F.; Reinhoudt, D. N. Chem. Eur. J. 1996, 2, 436-445.

[33] Casnati, A.; Pochini, A.; Ungaro, R.; Ugozzoli, F.; Arnaud, F.; Fanni, S.; Schwing, M. J.; Egberink, R. J. M.; de Jong, F.; Reinhoudt, D. N. J. Am. Chem. Soc. 1995, 117, 2767-2777.

[34] Ungaro, R.; Casnati, A.; Ugozzoli, F.; Pochini, A.; Dozol, J. F.; Hill, C.; Rouquette, H. Angew. Chem., Int. Ed. Engl. 1994, 33, 1506-1509.

[35] Gutsche, C. D.; Levine, J. A.; Sujeeth, P. K. J. Org. Chem. 1985, 50, 5802-5806. 


\section{Captions:}

Figure 1 : Synthetic pathway for phosphonic acid)calix[4]arenes possessing an anchoring arm. 

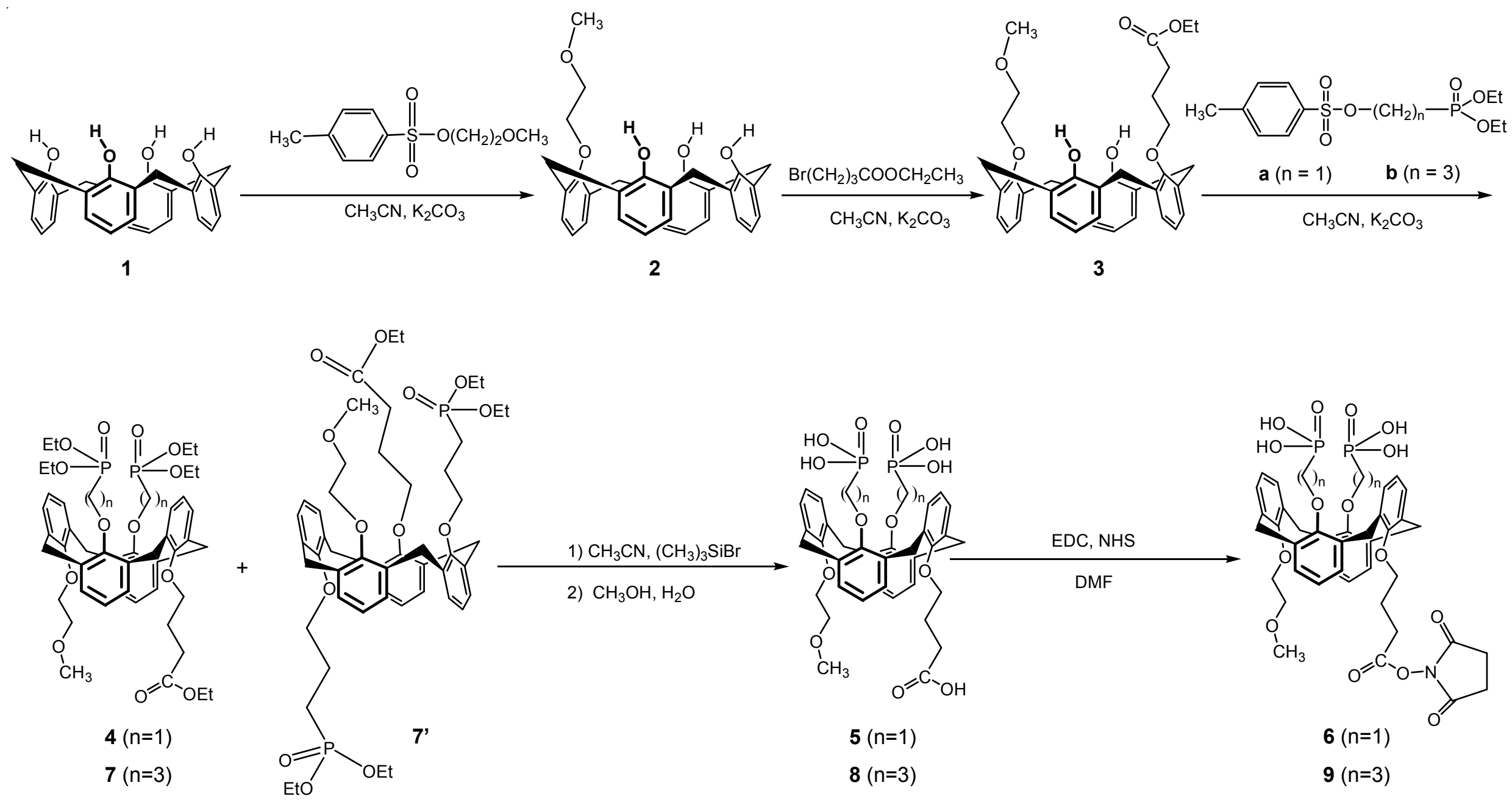
Table 1 : Successive couplings of calixarene 6 on the same gel

\begin{tabular}{cccc}
\hline Experiment number & $\begin{array}{c}\text { Addition of calixarene } \mathbf{6} \\
(\mu \mathrm{mol})\end{array}$ & $\begin{array}{c}\text { Calixarene } \mathbf{6} \text { found in the } \\
\text { eluate }(\mu \mathrm{mol})\end{array}$ & $\begin{array}{c}\text { \% calixarene } \mathbf{6} \\
\text { coupled to the gel }\end{array}$ \\
\hline 1 & 2.99 & 1.99 & 33.5 \\
2 & 2.99 & 1.97 & 34.1 \\
3 & 6.00 & 6.15 & - \\
\hline
\end{tabular}

